Saudi Journal of Pathology and Microbiology

Abbreviated Key Title: Saudi J Pathol Microbiol

ISSN 2518-3362 (Print) IISSN 2518-3370 (Online)

Scholars Middle East Publishers, Dubai, United Arab Emirates

Journal homepage: http://scholarsmepub.com/sjpm/

Original Research Article

\title{
Evaluation of Haemtalogical Parameters of Patients with Asthma in Southeast, Nigeria
}

\author{
Obeagu Emmanuel Ifeanyi ${ }^{1,2^{*}}$, Vincent $\mathrm{CCN}^{3}$ and Anaebo Queen Braxton $\mathrm{N}^{4}$ \\ ${ }^{1}$ Medical Laboratory Science, University Health Services, Michael Okpara University of Agriculture, Umudike, Abia State, Nigeria \\ ${ }^{2}$ Department of Medical Laboratory Science, Imo State University, Owerri, Nigeria \\ ${ }^{3}$ Department of Nursing Science, Imo State University, Owerri, Nigeria \\ ${ }^{4}$ Department of Accident/Emergency, Lagos University Teaching Hospital, Lagos, Nigeria
}

\begin{tabular}{l|l}
\hline DOI: $10.36348 / S J P M .2019 . v 04 i 10.009$ & Received: $12.10 .2019 \mid$ Accepted: $24.10 .2019 \mid$ Published: 30.10 .2019 \\
*Corresponding author: Obeagu Emmanuel Ifeanyi &
\end{tabular}

\section{Abstract}

The study was done to determine the levels of changes in haematological parameters in patients with asthma in Southeast, Nigeria. A total of 200 subjects were recruited for the study comprising 100 subjects each for Patients with asthma (50 subjects were Males, 50 were Females) and 100 subjects for apparently healthy subjects (Control) (50 subjects were Males, 50 were Females) drawn from a tertiary health institution. About $3 \mathrm{ml}$ of venous blood was aseptically collected from the antecubital vein of each subject by standard technique and was dispensed into an EDTA bottle for haematological parameters determination. The haematological parameters were determined using Mindray BC5300. The results were expressed as mean \pm standard deviation. The data were analysed with the statistical package for social science (SPSS) version 21 using t-test, ANOVA and the level of significance was set at $\mathrm{P}<0.05$. The study showed increase $(\mathrm{P}<0.05)$ in $\mathrm{WBC}(9.63 \pm 4.51 \mathrm{X} 109 / \mathrm{L}, 4.88 \pm 0.19 \mathrm{X} 109 / \mathrm{L}, \mathrm{P}=0.047)$, decrease $(\mathrm{P}<0.05)$ in $\mathrm{MCV}(85.26 \pm 4.20 \mathrm{fl}$, $90.01 \pm 0.05 f l, P=0.035), \mathrm{MCH}(27.54 \pm 1.09 \mathrm{pg}, 30.00 \pm 0.17 \mathrm{pg}, \mathrm{P}=0.001), \mathrm{MCHC}(325.20 \pm 4.97 \mathrm{~g} / 1,333.34 \pm 0.07 \mathrm{~g} / \mathrm{l}$, $\mathrm{P}=0.006)$ and no significant difference $(\mathrm{P}>0.05)$ in Neutrophils $(70.02 \pm 9.44 \%, 66.40 \pm 3.56 \%, \mathrm{P}=0.446)$, Lymphocytes $(28.38 \pm 10.20 \%, 31.39 \pm 3.88 \%, \mathrm{P}=0.554)$, Monocytes $(1.50 \pm 0.50 \%, 1.70 \pm 0.45 \%, \mathrm{P}=0.524)$,Eosinophils $0.53 \pm 0.23 \%, 0.51 \pm 0.45 \%, \mathrm{P}=0.959)$, Red blood cell (4.82 \pm 0.39 X1012/L, 5.04 \pm 0.51 X1012/L, P=0.435), Haemoglobin $(13.78 \pm 1.36 \mathrm{~g} / \mathrm{dl}, 15.13 \pm 1.52 \mathrm{~g} / \mathrm{dl}, \mathrm{P}=0.175)$, Packed cell volume $(41.60 \pm 3.78 \%, 45.40 \pm 4.56 \%, \mathrm{P}=0.189)$ and Platelets(255.40 $\pm 58.16 X 109 / \mathrm{L}, 222.00 \pm 37.01 X 109 / \mathrm{L}, \mathrm{P}=)$ of patients with asthma relative to control. The results showed decrease $(\mathrm{P}<0.05) \quad$ in $\quad$ Neutrophils $(60.50 \pm 3.54 \%, \quad 76.37 \pm 4.56 \%, \mathrm{P}=\quad 0.026)$, Monocytes $(1.00 \pm 0.01 \%, 1.83 \pm 0.29 \%, \mathrm{P}=0.030)$, increase $(\mathrm{P}<0.05)$ in Lymphocytes $(38.50 \pm 2.12 \%, 21.63 \pm 5.92 \%, \mathrm{P}=0.034), \mathrm{MCH}$ (28.60 $\pm 0.28 \mathrm{pg}, 26.83 \pm 0.65 \mathrm{pg}, \mathrm{P}=0.040)$, and no significant difference $(\mathrm{P}>0.05)$ in $\mathrm{WBC}(7.76 \pm 3.05,10.86 \pm 5.51$, $\mathrm{P}=0.533)$, Eosinophils $(1.09 \pm 0.29 \%, 0.15 \pm 0.03 \%, \mathrm{P}=0.261)$, RBC (4.96 $\pm 0.52 \mathrm{X} 1012 / \mathrm{L}, 4.71 \pm 0.37 \mathrm{X} 1012 / \mathrm{L}, \mathrm{P}=0.574)$, Haemoglobin $\quad(14.15 \pm 1.34 \mathrm{~g} / \mathrm{dl}, \quad 15.13 \pm 1.52 \mathrm{~g} / \mathrm{dl}, \quad \mathrm{P}=0.686), \quad \mathrm{PCV} \quad(42.50 \pm 3.54 \%, 41.00 \pm 4.58 \%, \quad \mathrm{P}=0.726)$, $\operatorname{MCV}(88.90 \pm 0.71 \mathrm{fl}, \quad 82.83 \pm 3.59 \mathrm{fl}, \quad \mathrm{P}=0.111), \quad \mathrm{MCHC}(321.00 \pm 5.66 \mathrm{~g} / \mathrm{l}, \quad 328.00 \pm 2.00 \mathrm{~g} / \mathrm{l}, \quad \mathrm{P}=0.127)$ and Platelets $(207.00 \pm 7.07 \times 109 / \mathrm{L}, 287.67 \pm 53.26 \mathrm{X} 109 / \mathrm{L}, \mathrm{P}=0.136)$ of patients with asthma of the male and female respectively. The results showed increase $(\mathrm{P}<0.05)$ in $\mathrm{MCHC}(327.25 \pm 2.22 \mathrm{~g} / \mathrm{l}, 317.00 \pm 1.07 \mathrm{~g} / \mathrm{l}, \mathrm{P}=0.026)$, decrease $(\mathrm{P}<0.05)$ in eosinophils $(0.16 \pm 0.02 \%, 2.00 \pm 0.01 \%, \mathrm{P}=0.000)$. The study revealed changes in the white cells and red cell indices. The clinicians and all the health workers should monitor these changes in the blood cells to manage the asthma patients for a better wellbeing.

Keywords: Haemtalogical Mindray Asthma.

Copyright @ 2019: This is an open-access article distributed under the terms of the Creative Commons Attribution license which permits unrestricted use, distribution, and reproduction in any medium for non-commercial use (NonCommercial, or CC-BY-NC) provided the original author and sources are credited.

\section{INTRODUCTION}

Asthma is shown to be a common chronic inflammatory disease of the airways of the lungs [1]. It is marked by alterable and recurring symptoms, reversible airflow blockage, and easily leads to bronchospasms [2]. Symptoms involve wheezing, coughing, chest tightness, and shortness of breath [3].
There was a report in 2015 that 358 million people globally had asthma, up from 183 million in 1990 [4]. It caused about 397,100 deaths in 2015 [4], most of which occurred in the developing world [1]. 
It has shown that asthma is twice as common in boys as girls, but severe asthma occurs at equal rates [5]. In contrast adult women have a higher rate of asthma than men and it is more common in the young than the old which may be linked to exposure to allergens as they more active with the environment than the older persons in the society [6]. Globally, prevalence of asthma has been elevated significantly between the 1960s and 2008 [7, 8] with it being observed as a main public health challenge since the 1970s [6].

Allergy is a disorder of the immune system as hypersensitivity response due to allergens. Asthma affects the airways that carry air to and from lungs. The inside walls of airways of asthmatic patients can be swollen or inflamed. As inflammation causes the airways to become narrower, less air can pass through them, results tissue hypoxia and/or hypoxemia [9, 10]. Asthma is a public health problem in all countries regardless of the level of development that 235 million people currently suffer from asthma [11].

The study was to done to determine the level of changes in haematological parameters in patients with asthma in Southeast, Nigeria.

\section{Study Area} Enugu, Nigeria.

The study was done in Parklane Hospital,

\section{Subjects}

A total of 200 subjects were recruited for the study comprising 100 subjects each for Patients with asthma (50 subjects were Males, 50 were Females) and 100 subjects for apparently healthy subjects (Control) (50 subjects were Males, 50 were Females) drawn from the Health institution.

\section{Sample collection}

About $3 \mathrm{ml}$ of venous blood was aseptically collected from the antecubital vein of each subject by standard technique was dispensed into an EDTA bottle for haematological parameters determination.

\section{Haematological investigations \\ The haematological parameters were determined using Mindray BC-5300. The} haematological parameters investigated include WBC, Neutrophils, Lymphocyets, Monocyets, Eosinophils, $\mathrm{RBC}$, Haemoglobin, PCV, MCV, MCH, MCHC and Platelets.

\section{Ethical Consideration}

The details of the research were explained to the subjects and written consents obtained from them and were assured of joining the study willingly and confidentiality also assured. The subjects who gave their consents were allowed to participate in the study.

\section{STATISTICAL ANALYSIS}

The results were expressed as mean \pm standard deviation. The data were analysed with the statistical package for social science (SPSS) version 21 using $\mathrm{t}$ test, ANOVA and the level of significance was set at $\mathrm{P}<0.05$.

Table-1: Mean \pm sd values of haematological paramters of patients with asthma and control

\begin{tabular}{|l|l|l|l|}
\hline Parameters & Asthma & Control & P-Value \\
\hline WBC $\left(\mathrm{X} 10^{9} / \mathrm{L}\right)$ & $9.63 \pm 4.51$ & $4.88 \pm 0.19$ & $0.047^{*}$ \\
\hline Neutrophil $(\%)$ & $70.02 \pm 9.44$ & $66.40 \pm 3.56$ & $0.446^{\mathrm{NS}}$ \\
\hline Lymphocyte(\%) & $28.38 \pm 10.20$ & $31.39 \pm 3.88$ & $0.554^{\mathrm{NS}}$ \\
\hline Monocyte(\%) & $1.50 \pm 0.50$ & $1.70 \pm 0.45$ & $0.524^{\mathrm{NS}}$ \\
\hline Eosinophil $(\%)$ & $0.53 \pm 0.23$ & $0.51 \pm 0.45$ & $0.959^{\mathrm{NS}}$ \\
\hline RBC $\left(\mathrm{X} 10^{12} / \mathrm{L}\right)$ & $4.82 \pm 0.39$ & $5.04 \pm 0.51$ & $0.435^{\mathrm{NS}}$ \\
\hline Haemoglobin $(\mathrm{g} / \mathrm{dl})$ & $13.78 \pm 1.36$ & $15.13 \pm 1.52$ & $0.175^{\mathrm{NS}}$ \\
\hline PCV(\%) & $41.60 \pm 3.78$ & $45.40 \pm 4.56$ & $0.189^{\mathrm{NS}}$ \\
\hline MCV $(\mathrm{fl})$ & $85.26 \pm 4.20$ & $90.01 \pm 0.05$ & $0.035^{*}$ \\
\hline MCH$(\mathrm{pg})$ & $27.54 \pm 1.09$ & $30.00 \pm 0.17$ & $0.001^{*}$ \\
\hline MCHC $(\mathrm{g} / \mathrm{l})$ & $325.20 \pm 4.97$ & $333.34 \pm 0.07$ & $0.006^{*}$ \\
\hline Platelets(X10 $/ \mathrm{L})$ & $255.40 \pm 58.16$ & $222.00 \pm 37.01$ & $0.310^{\mathrm{NS}}$ \\
\hline
\end{tabular}

The study showed increase $(\mathrm{P}<0.05)$ in WBC( $\left.9.63 \pm 4.51 \times 10^{9} / \mathrm{L}, 4.88 \pm 0.19 \times 10^{9} / \mathrm{L}, \quad \mathrm{P}=0.047\right)$, decrease $(\mathrm{P}<0.05)$ in MCV $(85.26 \pm 4.20 \mathrm{fl}, 90.01 \pm 0.05 \mathrm{fl}$, $\mathrm{P}=0.035) \quad, \quad \mathrm{MCH} \quad(27.54 \pm 1.09 \mathrm{pg}, 30.00 \pm 0.17 \mathrm{pg}$, $\mathrm{P}=0.001)$, MCHC $(325.20 \pm 4.97 \mathrm{~g} / \mathrm{l}, 333.34 \pm 0.07 \mathrm{~g} / \mathrm{l}$, $\mathrm{P}=0.006)$ and no significant difference $(\mathrm{P}>0.05)$ in Neutrophils $(70.02 \pm 9.44 \%, 66.40 \pm 3.56 \%, P=0.446)$, Lymphocytes $(28.38 \pm 10.20 \%, 31.39 \pm 3.88 \%, \mathrm{P}=0.554)$,
Monocytes $\quad(1.50 \pm 0.50 \%, 1.70 \pm 0.45 \%, \quad \mathrm{P}=0.524)$, Eosinophils $(0.53 \pm 0.23 \%, 0.51 \pm 0.45 \%, \mathrm{P}=0.959)$, Red blood cell $\left(4.82 \pm 0.39 \times 10^{12} / \mathrm{L}, 5.04 \pm 0.51 \times 10^{12} / \mathrm{L}\right.$, $\mathrm{P}=0.435)$ Haemoglobin $\quad(13.78 \pm 1.36 \mathrm{~g} / \mathrm{dl}$, $15.13 \pm 1.52 \mathrm{~g} / \mathrm{dl}, \quad \mathrm{P}=0.175)$, Packed cell volume $(41.60 \pm 3.78 \%, 45.40 \pm 4.56 \%, \quad \mathrm{P}=0.189)$ and Platelets $\left(255.40 \pm 58.16 \times 10^{9} / \mathrm{L}, \quad 222.00 \pm 37.01 \times 10^{9} / \mathrm{L}, \quad \mathrm{P}=\right)$ of patients with asthma relative to control. 
Table-2: Mean \pm sd values of haematological paramters of patients with asthma based on sex

\begin{tabular}{|l|l|l|l|}
\hline Parameters & MALE & FEMALE & P-Value \\
\hline WBC $\left(\mathrm{X} 10^{9} / \mathrm{L}\right)$ & $7.76 \pm 3.05$ & $10.86 \pm 5.51$ & $0.533^{\mathrm{NS}}$ \\
\hline Neutrophil $(\%)$ & $60.50 \pm 3.54$ & $76.37 \pm 4.56$ & $0.026^{*}$ \\
\hline Lymphocyte $(\%)$ & $38.50 \pm 2.12$ & $21.63 \pm 5.92$ & $0.034^{*}$ \\
\hline Monocyte $(\%)$ & $1.00 \pm 0.01$ & $1.83 \pm 0.29$ & $0.030^{*}$ \\
\hline Eosinophil $(\%)$ & $1.09 \pm 0.29$ & $0.15 \pm 0.03$ & $0.261^{\mathrm{NS}}$ \\
\hline RBC $\left(\mathrm{X} 10^{12} / \mathrm{L}\right)$ & $4.96 \pm 0.52$ & $4.71 \pm 0.37$ & $0.574^{\mathrm{NS}}$ \\
\hline Haemoglobin & $14.15 \pm 1.34$ & $15.13 \pm 1.52$ & $0.686^{\mathrm{NS}}$ \\
\hline PCV $(\%)$ & $42.50 \pm 3.54$ & $41.00 \pm 4.58$ & $0.726^{\mathrm{NS}}$ \\
\hline MCV(fl) & $88.90 \pm 0.71$ & $82.83 \pm 3.59$ & $0.111^{\mathrm{NS}}$ \\
\hline MCH(pg) & $28.60 \pm 0.28$ & $26.83 \pm 0.65$ & $0.040^{*}$ \\
\hline MCHC(g/l) & $321.00 \pm 5.66$ & $328.00 \pm 2.00$ & $0.127^{\mathrm{NS}}$ \\
\hline Platelets(X10\%) & $207.00 \pm 7.07$ & $287.67 \pm 53.26$ & $0.136^{\mathrm{NS}}$ \\
\hline
\end{tabular}

The results showed decrease $(\mathrm{P}<0.05)$ in Neutrophils( $\quad 60.50 \pm 3.54 \%, \quad 76.37 \pm 4.56 \%, \mathrm{P}=0.026)$, Monocytes increase $(1.00 \pm 0.01 \%, 1.83 \pm 0.29 \%, \mathrm{P}=0.030)$, $(\mathrm{P}<0.05) \quad$ in $\quad$ Lymphocytes (38.50 $\pm 2.12 \%, 21.63 \pm 5.92 \%, \quad \mathrm{P}=0.034), \quad \mathrm{MCH}$

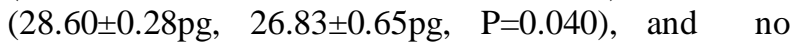
significant difference $(\mathrm{P}>0.05)$ in WBC $(7.76 \pm 3.05$, 10.86 $\pm 5.51, \quad \mathrm{P}=0.533), \quad$ Eosinophils $(1.09 \pm 0.29 \%, 0.15 \pm 0.03 \%, \mathrm{P}=0.261), \mathrm{RBC}(4.96 \pm 0.52$
$\left.\mathrm{X} 10^{12} / \mathrm{L}, 4.71 \pm 0.37 \mathrm{X} 10^{12} / \mathrm{L}, \mathrm{P}=0.574\right)$, Haemoglobin $(14.15 \pm 1.34 \mathrm{~g} / \mathrm{dl}, \quad 15.13 \pm 1.52 \mathrm{~g} / \mathrm{dl}, \quad \mathrm{P}=0.686), \quad \mathrm{PCV}$ $(42.50 \pm 3.54 \%, 41.00 \pm 4.58 \%$, $\mathrm{P}=0.726)$, $\operatorname{MCV}(88.90 \pm 0.71 \mathrm{fl}, \quad 82.83 \pm 3.59 \mathrm{fl}, \quad \mathrm{P}=0.111)$, $\mathrm{MCHC}(321.00 \pm 5.66 \mathrm{~g} / \mathrm{l}, 328.00 \pm 2.00 \mathrm{~g} / \mathrm{l}, \mathrm{P}=0.127)$ and Platelets $\left(207.00 \pm 7.07 \times 10^{9} / \mathrm{L}, 287.67 \pm 53.26 \times 10^{9} / \mathrm{L}\right.$, $\mathrm{P}=0.136)$ of patients with asthma of the male and female respectively.

Table-3: Mean \pm sd values of haematological paramters of patients with asthma based on age groups

\begin{tabular}{|l|l|l|l|}
\hline Parameters & 1-20 YEARS & 21-40 YEARS & P-Value \\
\hline WBC $\left(\mathrm{X} 10^{9} / \mathrm{L}\right)$ & $10.63 \pm 4.55$ & $5.60 \pm 0.29$ & $0.393^{\mathrm{NS}}$ \\
\hline Neutrophil $(\%)$ & $73.03 \pm 7.65$ & $58.00 \pm 4.56$ & $0.177^{\mathrm{NS}}$ \\
\hline Lymphocyte $(\%)$ & $25.48 \pm 9.08$ & $40.00 \pm 5.88$ & $0.248^{\mathrm{NS}}$ \\
\hline Monocyte $(\%)$ & $1.63 \pm 0.48$ & $1.00 \pm 0.25$ & $0.327^{\mathrm{NS}}$ \\
\hline Eosinophil $(\%)$ & $0.16 \pm 0.02$ & $2.00 \pm 0.01$ & $0.000^{*}$ \\
\hline RBC $\left(\mathrm{X} 10^{12} / \mathrm{L}\right)$ & $4.68 \pm 0.31$ & $5.32 \pm 0.02$ & $0.163^{\mathrm{NS}}$ \\
\hline Haemoglobin $(\mathrm{g} / \mathrm{dl})$ & $13.45 \pm 1.31$ & $15.10 \pm 0.52$ & $0.343^{\mathrm{NS}}$ \\
\hline PCV $(\%)$ & $40.75 \pm 3.77$ & $45.00 \pm 1.56$ & $0.388^{\mathrm{NS}}$ \\
\hline MCV $(\mathrm{fl})$ & $84.23 \pm 4.04$ & $89.40 \pm 2.05$ & $0.335^{\mathrm{NS}}$ \\
\hline MCH $(\mathrm{pg})$ & $27.33 \pm 1.12$ & $28.40 \pm 0.17$ & $0.453^{\mathrm{NS}}$ \\
\hline MCHC $(\mathrm{g} / \mathrm{l})$ & $327.25 \pm 2.22$ & $317.00 \pm 1.07$ & $0.026^{*}$ \\
\hline Platelets $\left(\mathrm{X} 10^{\%} / \mathrm{L}\right)$ & $268.75 \pm 57.64$ & $202.00 \pm 27.01$ & $0.376^{\mathrm{NS}}$ \\
\hline
\end{tabular}

The results showed increase $(\mathrm{P}<0.05)$ in MCHC $\quad(327.25 \pm 2.22 \mathrm{~g} / \mathrm{l}, \quad 317.00 \pm 1.07 \mathrm{~g} / \mathrm{l}, \quad \mathrm{P}=0.026)$, decrease $\quad(\mathrm{P}<0.05) \quad$ in $\quad$ Eosinophils $(0.16 \pm 0.02 \%, 2.00 \pm 0.01 \%, \mathrm{P}=0.000)$, and no significant difference $(\mathrm{P}>.05)$ in WBC $\left(10.63 \pm 4.55 \times 10^{9} / \mathrm{L}\right.$, $\left.5.60 \pm 0.29 \quad \mathrm{X} 10^{9} / \mathrm{L}, \quad \mathrm{P}=0.393\right), \quad$ Neutrophils (73.03 $\pm 7.65 \%, 58.00 \pm 4.56 \%, \quad \mathrm{P}=0.177)$, Lymphocytes $(25.48 \pm 9.08 \%, 40.00 \pm 5.88 \%, \quad \mathrm{P}=0.248), \quad$ Monocytes $(1.63 \pm 0.48 \%, 1.00 \pm 0.25 \%, \mathrm{P}=0.327), \mathrm{RBC}(4.68 \pm 0.31$ $\left.\mathrm{X} 10^{12} / \mathrm{L}, 5.32 \pm 0.02 \times 10^{12} / \mathrm{L}, \mathrm{P}=0.163\right)$, Haemoglobin $(13.45 \pm 1.31 \mathrm{~g} / \mathrm{dl}, \quad 15.10 \pm 0.52 \mathrm{~g} / \mathrm{dl}, \quad \mathrm{P}=0.343), \quad$ PCV $(84.23 \pm 4.04 \%, 45.00 \pm 1.56 \%, \quad \mathrm{P}=0.388), \quad \mathrm{MCH}$ $(27.33 \pm 1.12 \mathrm{pg}, \quad 28.40 \pm 0.17 \mathrm{pg}, \quad \mathrm{P}=0.453), \quad$ Platelets (268.75 $\pm 57.64,202.00 \pm 27.01, \mathrm{P}=0.376)$ of patients with asthma of 1-20 years and 21-40 years respectively.

\section{DISCUSSION}

Typical changes in the airways include an increase in eosinophils. Other cell types involved are T- lymphocytes, macrophages, and neutrophils. There may also be link to other components of the immune system [6]. The study showed increase in WBC which could be associated to oxidative stress and generation of reactive oxygen and free radical as a result of the asthma, decrease in $\mathrm{MCV}, \mathrm{MCH}, \mathrm{MCHC}$ which shows microcytic hypochromic anaemia in the patients and no significant difference in Neutrophils, Lymphocytes, Monocytes, Eosinophils, Red blood cell, Haemoglobin, Packed cell volume and Platelets of patients with asthma relative to control. The red cell line was not affected which means that the bone marrow function may not be altered.

The results showed decrease in Neutrophils, Monocytes, increase in Lymphocytes, $\mathrm{MCH}$, and no significant difference in WBC, Eosinophils, RBC Haemoglobin, PCV, MCV, MCHC and Platelets of patients with asthma of the male and female 
respectively. This shows that females may have increased stress linked to asthma compared to males due to increased level of neutrophils in female patients and also increased monocytes and lymphocyets leading to increased release of cytokines which may increase inflammation in female patients than the male patients. Haematological parameters have been reported as good markers for health and disease states [12-14].

The results showed increase in MCHC, decrease Eosinophil, and no significant difference $(\mathrm{P}>0.05)$ in WBC, Neutrophils, Lymphocytes, Monocytes, RBC, Haemoglobin, PCV, MCH, Platelets of patients with asthma of 1-20 years and 21-40 years respectively. The study revealed that the age group has no effect on the haematological parameters studied except the MCHC that decreased and eosinophils that increased in MCHC in patients with asthma of 1-20 years compared to 21-40 years. This shows that the allergic reactions is more pronounced in 1-0 years than in 21- years asthma patients and the clinicians and all the health workers managing the patients should take cognizance of this changes. I $t$ has been reported that hematological parameters can be affected by disease situations affecting hematopoietic function and linked to immunological reaction. Asthma is an allergic condition in humans [15-17].

\section{CONCLUSION}

The study revealed changes in the white cells and red cell indices. The clinicians and all the health workers should monitor these changes in the blood cells of patients with asthma to manage the patients for a better wellbeing as these changes could induce secretions of some immunoregulators like cytokines, chemokines and histomines that can affect the entire systems of the patients.

\section{REFERENCES}

1. British Guideline.(2009): 4

2. NHLBI. (2007). Guideline: 11-12

3. WHO. (2016). Asthma Fact sheet №307.

4. GBD. (2016). 2015 Mortality and Causes of Death, Collaborators. Global, regional, and national life expectancy, all-cause mortality, and cause-specific mortality for 249 causes of death, 1980-2015: a systematic analysis for the Global Burden of Disease Study 2015. Lancet. 388 (10053): 14591544.

5. Bush, A., \& Menzies-Gow, A. (2009). Phenotypic differences between pediatric and adult asthma. Proceedings of the American Thoracic Society, 6(8), 712-719.

6. Murray J.F. (2010). Ch. 38 Asthma. In Mason, R.J.; Murray, J.F., Broaddus, V.C. Nadel, J.A., Martin, T.R., King, Jr., Talmadge, E. and Schraufnagel, D.E. (eds.). Murray and Nadel's textbook of respiratory medicine (5th ed.). Elsevier.
7. Anandan, C., Nurmatov, U., van Schayck, O. C., \& Sheikh, A. (2010). Is the prevalence of asthma declining? Systematic review of epidemiological studies". Allergy. 65(2): 152-67.

8. Grant, E.N., Wagner, R., \& Weiss, K.B. (1999). Observations on emerging patterns of asthma in our society. J Allergy Clin Immunol. 104 (2 Pt 2): S1-S9.

9. World Health Organization (WHO). (2007). Global estimates of burden of disease caused by the environmental and occupational risks.

10. Khan, I.A., Arsalan, M.H., Siddiqu, I M.A., Zeeshan, S., \& Shaukat, S.S. (2010). Spatial association of asthma and vegetation in Karachi: A GIS perspective. Pak J Bot 42: 3547-3554.

11. Mosby. (2008). Mosby's Dental Dictionary. Second edition. Elsevier.

12. Obeagu, E.I., Obeagu, G.U., Chijioke, U.O. \& Ofor, I.B. (2017). Analysis of Alterations in Selected Haematological Parameters of Ascariasis Patients in Umudike, Abia State, Nigeria. Ann. Clin. Lab. Res. 5(3): 193.

13. Obeagu, E. I., Obeagu, G.U., \& Anaebo, Q.B.N. (2019). Studies on Serum Erythropoietin and Red Cell Indices of Patients with Urinary Tract Infection in Southeast, Nigeria. Saudi Journal of Biomedical Research, 4(10): 333-337.

14. Obeagu, E.I., Azuonwu, O., Didia, B.C., \& Obeagu, G.U. (2018). Determination of Haematological Changes Associated with Syphilis in Subjects in Umudike, Abia State, Nigeria. Cohesive Journal of Microbiology and Infectious Disease, 1(1): 505

15. Masoli, M., Fabian, D., Holt, S., \& Beasley, R. (2004).The global burden of asthma: executive summary of the GINA Dissemination Committee report. Allergy, 59: 469-478.

16. Smith, A.M., Villareal, M., Bernstein, D.I., \& Swikert, D.J. (2012). Asthma in the elderly: risk factors and impact on physical function. Ann Allergy Asthma Immunol, 108: 305-310.

17. World Health Organization. (WHO). (2007). Global surveillance, prevention and control of chronic respiratory diseases: a comprehensive approach.

18. GBD. (2015). Disease and Injury Incidence and Prevalence, Collaborators 2016. Global, regional, and national incidence, prevalence, and years lived with disability for 310 diseases and injuries, 1990 2015: a systematic analysis for the Global Burden of Disease Study 2015. Lancet. 388(10053): 15451602.

19. Global Burden of Disease Study 2013, Collaborators. (2015). Global, regional, and national incidence, prevalence, and years lived with disability for 301 acute and chronic diseases and injuries in 188 countries, 1990-2013: a systematic analysis for the Global Burden of Disease Study 2013. Lancet. 386 (9995): 743-800. 